\title{
Alternative methods for the wool wax extraction from wool scouring wastes
}

\author{
By M. López-Mesas ${ }^{\star a}$, F. Carrillo ${ }^{\mathrm{b}}$, M. C. Gutiérrez ${ }^{\mathrm{b}}$ and M. Crespi ${ }^{\mathrm{b}}$ \\ ${ }^{a}$ Centre GTS, Unitat de Química Analítica, Departament de Química, \\ Universitat Autònoma de Barcelona, Facultat de Ciències, Edifici CN, 08193-Bellaterra, \\ Barcelona, Spain. \\ bINTEXTER-UPC, Colom 15, 08222-Terrassa, Spain. \\ *Author whom correspondence should be sent. montserrat.lopez.mesas @uab.es
}

\section{RESUMEN}

Métodos alternativos para la extracción de la cera de lana contenida en efluentes residuales generados tras lavados industriales de lana.

Las fibras de lana, tras obtenerlas de las ovejas y antes de ser procesadas industrialmente, han de ser lavadas. Este proceso genera residuos altamente contaminantes que pueden obtenerse en dos formas diferentes, una fase líquida y una fase sólida. Ambas fases contienen, entre otros, una gran cantidad de la grasa generada por las ovejas y que se puede recuperar y purificar para obtener lanolina, un producto de alto valor industrial. Para evaluar la cantidad de grasa contenida en dichos efluentes, la técnica más extendida en los laboratorios es la extracción por Soxhlet, la cual consume tiempo y disolventes orgánicos pero obteniendo altos porcentajes de recuperación. En el presente trabajo se compara el porcentaje de recuperación de la cera de lana de efluentes industriales mediante técnicas alternativas a la tradicional (Microondas, Soxhlet automatizado y Fluidos Supercríticos) obteniendo recuperaciones del $100 \%$, reduciendo el tiempo de análisis, el consumo de disolvente y la generación de residuos.

PALABRAS-CLAVE: Cera de lana - Extracción por fluidos supercríticos - Microondas - Soxhlet automatizado.

\section{SUMMARY}

\section{Alternative methods for the wool wax extraction from} wool scouring wastes.

Wool fibers have to be properly washed out before being processed into fabrics. This scouring process generates high pollutant wastes in two forms, a liquid phase and a solid phase. Both phases contain a large amount of the grease (wool wax) generated by the animal which may be recovered and purified to obtain lanolin, a highly valued product. To evaluate the amount of grease in such wastes, Soxhlet extraction with organic solvent is the technique more widely used in laboratories worldwide as it provides a high grease recovery although it is a time and solvent consuming technique. The present work compares alternative extraction techniques to the Soxhlet extraction (Microwave, automated Soxhlet and Supercritical Fluids) recovering $100 \%$ of the grease, reducing the time of analysis, the solvent consumption and the waste generation.

KEY-WORDS: Automated Soxhlet - Microwave - Supercritical fluid extraction - Wool wax.

\section{INTRODUCTION}

Wool is an animal fiber used by humans since $4.000 \mathrm{BC}$. It is the fiber that protects and covers the body of some animals such as sheep, camels, etc. For human use, the mainly fiber used has been, over the time, the sheep wool. Once obtained the wool from the animal and before the processing, a thorough washing is necessary in order to ensure the quality of the final product. The original fiber is usually dirty with three different components, the animal grease, secreted by the sebaceous glands and usually called wool wax, the suintin, secreted by the sweat glands and the dirty related to the daily life of the animal. If the washing was not properly done, then the textile process parameters should be modified for every different wool origin and depending on the wax content what is undesirable for the textile wool industry (Baldwinson 1990, Stewart, 1965 and 1966, Walls 1963).

To remove the grease and the dirty materials the most commonly used method consumes large amounts of water and surfactants. The washing process generates a high contaminating wastewater with BOD about $20.000-40.000 \mathrm{mg} / \mathrm{l}$ and COD of $100.000 \mathrm{mg} / \mathrm{l}$ being the textile sector with the highest contaminating effluents (Norman and Seddon 1991). To reduce the generation of wastes, some washing plants recover part of the grease as a cream phase because the grease material, containing mainly the wool wax, remains in the superficial layer of the different washing tanks. Those superficial waters are centrifuged, and a cream phase is obtained. This cream phase is a valuable sub-product because can be sold as a source to obtain lanolin (after extraction and purification) which is a high value product in pharmaceutical applications and baby care products (Diserens 1989, Stewart and Story 1980, Goode 1963 and Clark 1990).

At the end of the washing process, the waters with the remaining material constitute the liquid phase. The liquid effluents of the washings are usually dried to reduce waste volume, generating a solid waste or sludge. Due to its high content in potassium and organic material this sludge could 
be used as fertilizer in agricultural. But in order to reuse any sewage sludge for agricultural purposes, the Council of the European Communities has adopted a Directive designed to protect the agricultural environment where it would be landed and which encourages the analysis of the components of the sludge (86/278/EEC).

To analyze the wax content in the effluents, a Soxhlet system has been traditionally used. The method is time and solvents consuming (4 hours and $125 \mathrm{ml}$ respectively) and generates an organic solvent waste which can be recovered by distillation. In this work, new developed techniques, automated Soxhlet, microwave and supercritical fluid extraction, will be applied and compared to the traditional technique to reduce time of analysis and solvent consumed.

\section{EXPERIMENTAL}

\section{Samples}

Two different kinds of samples (solid waste and cream phase) obtained from different scouring plants located in Australia and Europe (Spain and Italy), have been used in this study:

- Solid wastes, obtained as sludge after the washing up of the wool and dehydration, referenced in this work as $S_{i}\left(S_{i}=S_{1} \ldots S_{6}\right)$

- The cream phases, obtained after centrifugation of the superficial water from the first washing, referenced as $\mathrm{CP}_{\mathrm{i}}\left(\mathrm{CP}_{\mathrm{i}}=\mathrm{CP}_{1} \ldots\right.$ $\mathrm{CP}_{6}$ )

To avoid degradation, samples were stored at $-15^{\circ} \mathrm{C}$ when were not used or at $4^{\circ} \mathrm{C}$ while experiments were carried out.

\section{Characterization of the samples}

Samples were characterized following the methods developed by the Department of Environment of Catalonia (Pautes d'Anàlisi en Sòls Contaminats, Junta de Residus) and by the International Wool Secretariat (IWS: Report ET708). The amount of suintin, grease, dirty material, and dried residue were calculated. Also, FT-IR spectrum of the pure wool wax and the extracted material were obtained and compared.

\section{Soxhlet extraction}

To obtain the exact amount of wool grease in each sample, the established method ET-708 of the IWS for the extraction of the wool wax from sludge was the reference method followed. A classical Soxhlet system with cellulose extraction cartridges $\left(33^{\star} 80 \mathrm{~mm}\right)$ was employed. $5 \mathrm{~g}$ of sludge or cream phase were mixed with anhydrous sodium sulfate in order to eliminate water content, and placed into the cartridge with $125 \mathrm{ml}$ of dichloromethane. Extraction was performed for 4 hours, the solvent was evaporated and the percentage of extracted wax calculated by weight.

The extracts obtained by any of the methods described in this work, were dried in a heater at $60^{\circ} \mathrm{C}$ to constant weight.

\section{Automated Soxhlet System}

The equipment used was a Soxtec System HT2 from Tecator with cellulose extraction cartridges $\left(33^{\star} 80 \mathrm{~mm}\right)$ and stainless steal glasses.

This method, which has been applied in sample preparation for the analysis of micropollutans (Sturaro et al. 1993) and for the extraction of grease from cotton fibers (Martinez et al. 1997), is based on the Soxhlet system but the extraction is performed in three steps. In the first step, the cartridge with the sample was submerged inside the heated solvent. During the second step, the cartridge was placed over the solvent and the condensed solvent passes through the cartridge. In the last step, the evaporated solvent was retained in the condenser. The time for each step was optimized at 60,60 and 5 minutes respectively. The total time of extraction was approx. $2 \mathrm{~h}$, and the volume of solvent consumed was $50 \mathrm{ml}$. About a 50$60 \%$ of the solvent was recovered and ready for reuse.

In the present work, six solvents were compared, those usually employed for Soxhlet extraction: acetone, dichloromethane, acetone:hexane 1:1, toluene, dichloromethane:hexane 1:1 and ethanol. The influence of the addition of anhydrous sodium sulfate to the samples with no further treatment of the sample was also tested.

\section{Microwave extraction}

Microwave procedures have been widely used for sample digestion in atomic spectrometric analysis (Matusiewicz et al. 1988, Chakraborty et al. 1996, Pérez-Cid et al. 1999, Michael et al. 1991), for the acceleration of organic reactions (Bordera et al. 1996, Sturgeon et al. 1995) and lately some work has been made as a technique for sample extraction (de Pedro et al. 1997, García-Ayuso et al. 1999).

For the present study, a Q-45 EnviroPrep (750 W and $2450 \mathrm{MHz}$ ) from Questron Corporation was employed.

The parameters for the extraction of pure wool wax were optimized in our previous work (LópezMesas et al. 2003) and were selected as follows. 1.25 grams of non dried sample for sludge or 0.50 grams for cream phase were extracted using $10 \mathrm{ml}$ of acetone:hexane $1: 1$, for $8 \mathrm{~min}$ and at $90 \%$ of the power of the equipment. Once cooled to room temperature, samples were filtered through a $0.45 \mu \mathrm{m}$ syringe Teflon filter. The extract was allowed to evaporate to dryness in a sand bath, below $60^{\circ} \mathrm{C}$. 


\section{Supercritical Fluid Extraction}

The extraction of any kind of grease or wax by supercritical fluids is not a largely developed application of the supercritical fluid extraction but recent studies have shown the applicability for the extraction of this kind of grease (Jones et al. 1997, Marsal et al. 2000, López-Mesas et al. 2005).

The extractions were performed on an ISCO SFX2-10 (Lincoln, NE) with supercritical $\mathrm{CO}_{2}(\mathrm{BOC}$ Gases, Melbourne, Australia) which was supplied by an ISCO 100DX syringe pump following a procedure we developed in a previous work (LópezMesas et al. 2005) and selected as follows: $0.3 \mathrm{~g}$ of sample was thoroughly mixed with $1 \mathrm{~g}$ of Chromosorb W-HP (60-80 mesh, Manville, Denver, $\mathrm{CO}$ ) and $0.6 \mathrm{~g}$ of anhydrous sodium sulphate. The mixture was placed into a $10 \mathrm{ml}$ stainless steel cartridge. To avoid the risk of unextracted wool wax entering into the supercritical fluid effluent, the mixture was placed between two layers of uncoated Chromosorb, and finally $3 \mathrm{ml}$ of toluene, used as a cosolvent, were added to the top. The cartridge was properly closed and placed into the extractor chamber. Then, the chamber temperature was programmed to $80^{\circ} \mathrm{C}$ and the fluid was allowed to enter into the cell to the selected pressure, $250 \mathrm{~atm}$. After an equilibration time of 40 minutes, valves were opened and the extracting fluid (dragging the extracted components) was delivered through a restrictor (selected at $80^{\circ} \mathrm{C}$ ) to a pre-weighed vial with $6 \mathrm{ml}$ of toluene. Toluene was evaporated under a nitrogen flux and the amount of wax was calculated by weight difference.

\section{RESULTS AND DISCUSSION}

\section{Characterization of the samples}

The amount of grease was calculated by the Soxhlet extraction method established by the International Wool Secretariat as previously cited. As shown in figure 1, the amount of grease content

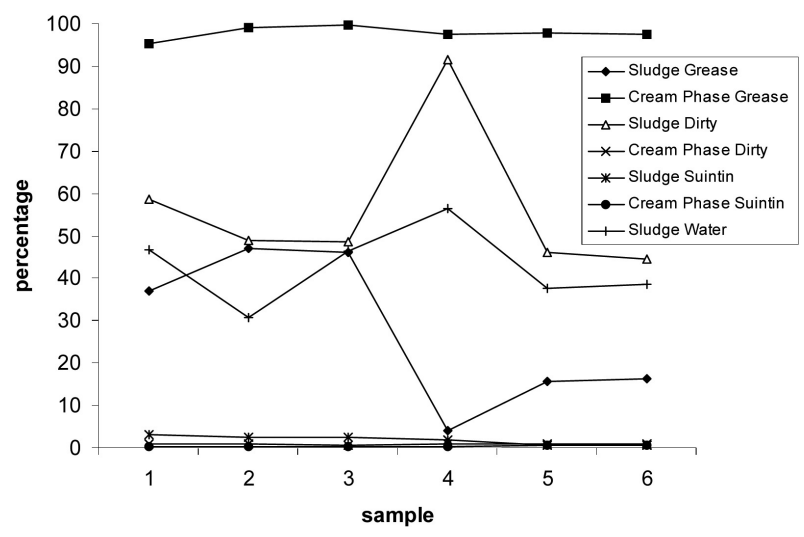

Figure 1.

Percentages of dirt, grease, suintin and water for six samples of cream phase and six samples of sludge (percentage per weight of sample), showing the heterogeneity of the samples. in the different sludge samples were within a wide range, from $4.12 \%$ to $47.14 \%$. For the cream phases the amount of grease varied from $95.23 \%$ to $99.60 \%$.

The water content varied from $30.70 \%$ to $56.29 \%$ for the sludge samples (RSD bellow $1.45 \%$ ), which depends on the industrial process of drying the waste.

Suintin and dirt contents also showed random values for the sludge samples, from $0.50 \%$ to $3.07 \%$ and $43.72 \%$ to $91.42 \%$ respectively (RSD bellow $0.17 \%$ for suintin and $0.74 \%$ for dirty). The variability for the cream phases samples was lower, varying from $0.18 \%$ to $0.56 \%$ and $0.55 \%$ to $0.96 \%$ respectively due to the high percentage of grease (RSD bellow 0.06\%).

The results of the characterization show the non homogeneity of the sludge samples which depends on the origin of the samples and the drying process.

\section{Extraction of the wax}

Extractions of the wax contained in six samples of sludge and six cream phases were processed at least in duplicate according to the different methods described in the Experimental section and results are discussed below.

\section{Automated Soxhlet Extraction}

A sludge sample was extracted by the traditional Soxhlet method obtaining a $42.5 \%$ of wool wax (w/w of dried sample). The same sample was extracted by Soxtec with the different solvents mentioned in the previous section. Of the different solvents tested, acetone: hexane 1:1, toluene and dichloromethane: hexane 1:1, showed a result in agreement with the Soxhlet system, between 41.8 and $42.5 \%$ (figure 2). With ethanol, due to its polarity, the result was less than a $24.0 \%$. Acetone and dichloromethane showed intermediate recoveries between 36.0 and $37.5 \%$. Acetone:hexane was the selected solvent because of its lower boiling point (RSD bellow $1.2 \%)$.

This kind of sludge is not water free, because the drying process is not complete, and the presence of water may decrease the extraction rate because of its polarity. Since the extractions were performed with the sample as it was received, to avoid loss of volatile compounds for possible further analysis of the sample, and to minimize the problem, different amounts of anhydrous sodium sulfate were added to $5 \mathrm{~g}$ of sample and were thoroughly mixed. Results are shown in figure 3 , and as can be seen, the addition of 1.5 times the amount of the sample was necessary to ensure the maximum extraction of the wax.

Once the method was optimized for the extraction of the $100 \%$ of the wax contained in the sample, only some of the samples were available for extraction. 


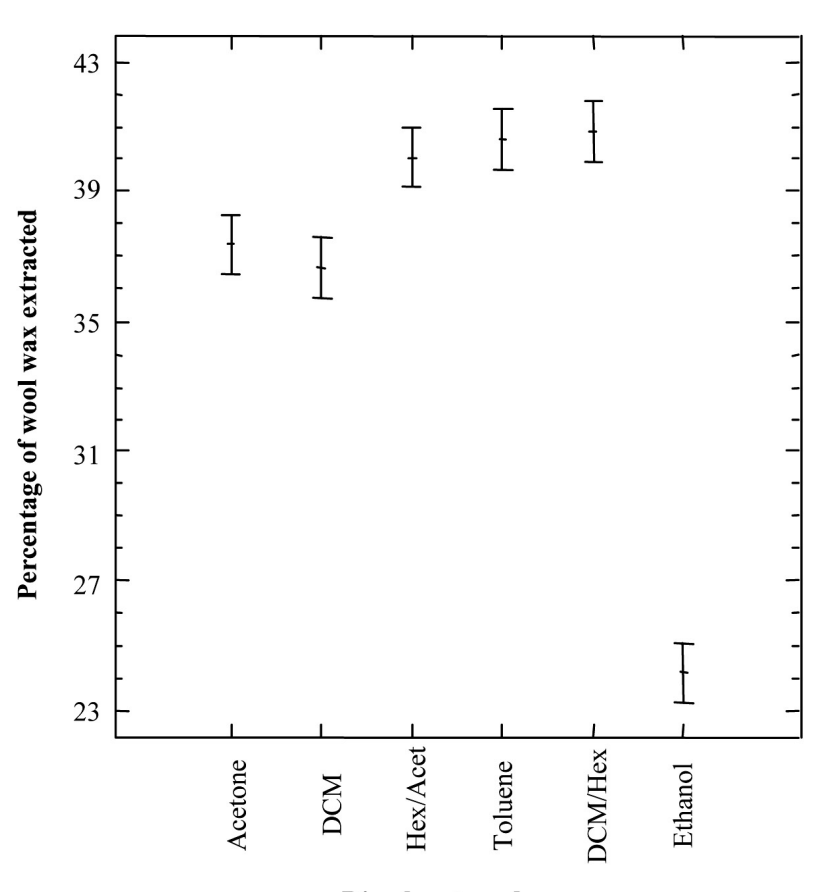

Dissolvent used

Figure 2

Effect of the nature of the solvent on wool wax extraction by the automated Soxhlet system. By the reference method, Soxhlet, the sample showed $42.5 \%$.

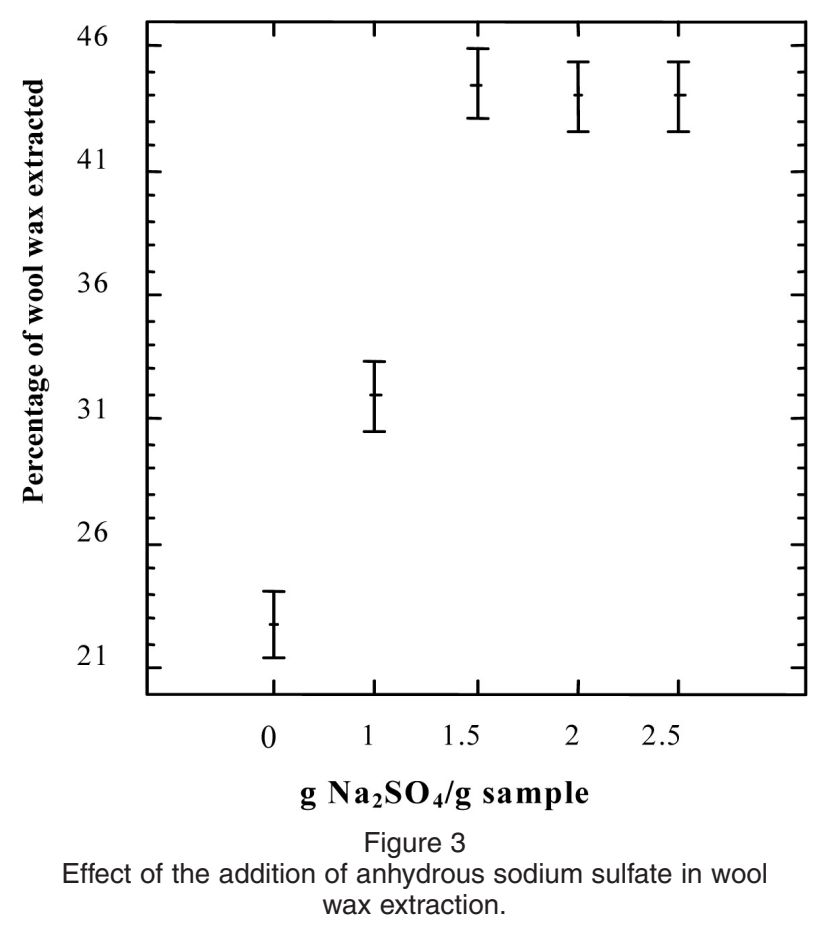

\section{Comparison of the amount of wax recovered}

The results obtained for the extraction of the wax contained in different scouring plant samples are summarized in Table 1. Results are expressed as the factor $f$ (wax extracted by the optimized method divided by wax extracted by the traditional Soxhlet technique).

As can be seen, factor $f$ is greater than 0.97 and always close to 1.00 , indicating that the amount of
Table 1

Wax extracted expressed as $\mathrm{f}$ factor (amount extracted by the method studied/amount extracted by Soxhlet method). $S_{i}=$ Sludge, $\mathrm{CP}_{\mathrm{i}}=$ Cream Phase.

\begin{tabular}{cccc}
\hline Sample & $\begin{array}{c}\text { Soxtec } \\
\text { Extraction }\end{array}$ & $\begin{array}{c}\text { Microwave } \\
\text { Extraction }\end{array}$ & $\begin{array}{c}\text { Supercritical } \\
\text { Fluid } \\
\text { Extraction }\end{array}$ \\
\hline $\mathrm{S}_{1}$ & 0.99 & 1.00 & - \\
$\mathrm{S}_{2}$ & 1.01 & 1.00 & - \\
$\mathrm{S}_{3}$ & 1.02 & 0.99 & - \\
$\mathrm{S}_{4}$ & - & - & 1.02 \\
$\mathrm{~S}_{5}$ & - & - & 0.99 \\
$\mathrm{~S}_{6}$ & - & - & 1.01 \\
$\mathrm{CP}_{1}$ & - & 1.03 & 0.99 \\
$\mathrm{CP}_{2}$ & 0.99 & 0.99 & 0.98 \\
$\mathrm{CP}_{3}$ & - & 1.02 & 1.01 \\
$\mathrm{CP}_{4}$ & 0.99 & 0.97 & 0.97 \\
$\mathrm{CP}_{5}$ & - & 0.97 & 0.99 \\
$\mathrm{CP}_{6}$ & - & 0.99 & 0.99 \\
\hline
\end{tabular}

wax recovered by any of the methods and for all the samples analyzed showed no significant differences compared to the wax recovered by the traditional technique.

\section{Comparison of the time needed for the extraction}

Considering only the time needed for the extraction (running time of the equipment), the Soxhlet system needs 4 hours to complete the extraction, the automation of the system (Soxtec) reduces the time to 2 hours, the supercritical fluid extraction takes 45 minutes and the fastest of the tested methods was microwave extraction, requiring only 8 minutes for the total extraction of the wax with the consequent reduction in energy consumption.

Another consideration to take into account for the reduction in time analysis is the amount of samples that can be extracted per analysis. In the automated Soxhlet and supercritical fluid equipments the extraction of only two samples may be done at the same time. For the microwave system, eight samples could be extracted at the same time (the system allows up to twelve samples per round but best recoveries are guaranteed for no more than eight samples as our previous studies had shown (López-Mesas et al. 2003)). Notice that it depends on the equipment used in the present work, but it is the most commonly used equipment in most of the laboratories.

\section{Comparison of the amount and type of solvent consumed}

Soxhlet extraction uses $125 \mathrm{ml}$ of solvent per sample which can be partially recovered if a distillation of every sample is performed after the four hours of extraction, which largely increases the time of analysis and energy consumption. This 
problem is reduced in the automated version where $50 \mathrm{ml}$ are used and after the two hours of extraction about $50-60 \%$ of the solvent is recovered with no further time, equipment or processing needed. With microwave and supercritical fluid extraction there are no recovering of the solvents employed for the extraction but only 10 to $15 \mathrm{ml}$ are used (a lower amount than that lost by Soxhlet and Soxtec).

Moreover, the Soxhlet extraction is usually performed with dichloromethane, a solvent that exposes to a high toxicity, both to the analyst and the environment. It can be replaced by acetone:hexane in the automated Soxhlet version and the microwave extraction. A mixture of a non halogenated solvents, also toxic but in a lower amount is used so the exposure is also reduced. In the case of supercritical fluid extraction, an inert solvent, $\mathrm{CO}_{2}$, is used.

\section{Comparison of the infrared spectra}

FT-IR spectra were obtained for the grease extracted by microwave and automated Soxhlet. Also, infrared spectrum for a sample of a commercial pure wool wax (Sigma, Spain) was obtained. Spectra are shown in figure 4.

As can be seen, the most principal and characteristic bands found in pure wool wax spectra are also found in the extracted wax. Those bands belong to the organic acids, esters of organic acids and tertiary alcohols, mainly products expected to be found in this kind of wax. Spectra show a non significant degradation of the products composing the wool wax.

\section{CONCLUSIONS}

Obtained recoveries for the wax contained in samples provided by different wool scouring plants, are in agreement with the amount obtained by the traditional extraction technique, so any of the techniques could be used by any laboratory to perform the analysis of the amount of wax in sludge or cream phases samples.

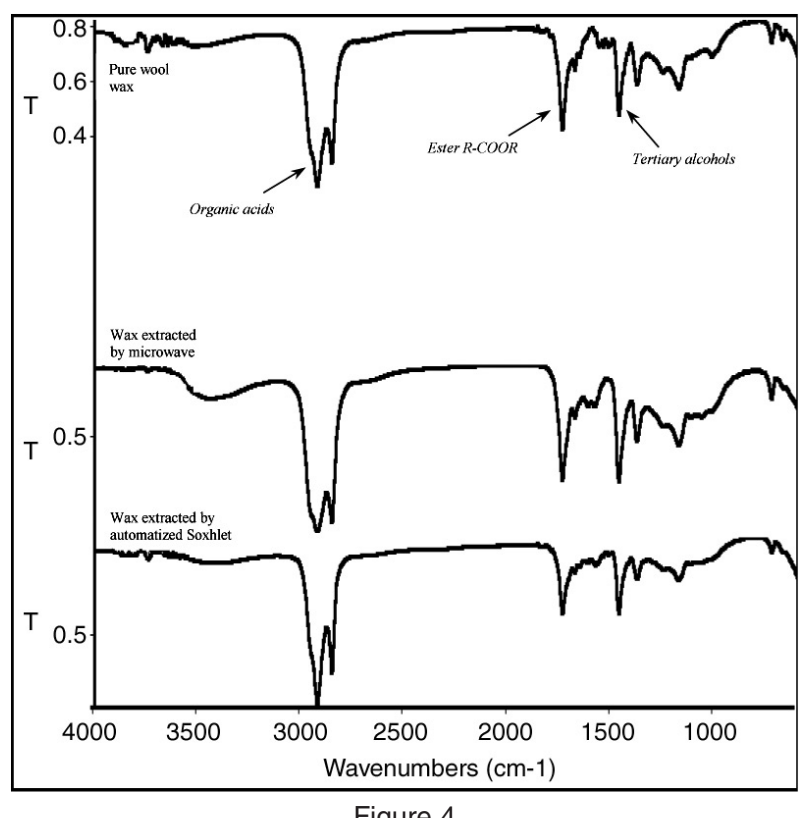

Infrared spectra for a sample of pure wool wax and the wax extracted by microwave and automated Soxhlet.

Moreover, the techniques tested present characteristics which may make them greener alternatives. Table 2 shows the parameters selected for the different techniques. Time analysis is considerably reduced (from 4 hours with the traditional Soxhlet to 8 minutes with microwave), with the additional reduction in energy consumption due to the reduction in running time of the equipment. The amount of solvent is also reduced (from $125 \mathrm{ml}$ for the traditional technique to $10 \mathrm{ml}$ in microwave and supercritical fluids). The hazard potential was also reduced (from a toxic halogenated compound in Soxhlet extraction to a less toxic or inert compound in microwave or supercritical fluids extraction respectively).

In conclusion, traditional Soxhlet technique can be replaced by new developed techniques that are less consuming in solvent and analysis time and safer for the analyst and the environment being consequently greener techniques.

Table 2

Parameters of the compared extraction techniques.

\begin{tabular}{|c|c|c|c|c|}
\hline Parameter & $\begin{array}{c}\text { Soxhlet } \\
\text { Extraction } \\
\text { (traditional) }\end{array}$ & $\begin{array}{c}\text { Automated } \\
\text { Soxhlet } \\
\text { Extraction }\end{array}$ & $\begin{array}{l}\text { Microwave } \\
\text { Extraction }\end{array}$ & $\begin{array}{c}\text { Supercritical } \\
\text { Fluids } \\
\text { Extraction }\end{array}$ \\
\hline Solvent & Dichloromethane & $\begin{array}{c}\text { Acetone:Hexane } \\
1: 1\end{array}$ & $\begin{array}{c}\text { Acetone:Hexane } \\
1: 1\end{array}$ & $\begin{array}{l}\text { Carbon } \\
\text { dioxide }\end{array}$ \\
\hline $\begin{array}{l}\text { Volume } \\
\text { of solvent }\end{array}$ & $125 \mathrm{ml}$ & $50 \mathrm{ml}$ & $10-15 \mathrm{ml}$ & $10 \mathrm{ml}$ \\
\hline $\begin{array}{l}\text { Solvent } \\
\text { recuperation? }\end{array}$ & $\begin{array}{c}\text { Only if } \\
\text { distillation } \\
\text { is performed }\end{array}$ & Yes, $50-60 \%$ & No & No \\
\hline $\begin{array}{c}\text { Extraction } \\
\text { time }\end{array}$ & 4 hours & 2 hours & 8 minutes & 45 minutes \\
\hline $\begin{array}{c}\text { Solvent } \\
\text { characteristics }\end{array}$ & Toxic & Toxic & Toxic & Inert \\
\hline
\end{tabular}




\section{ACKNOWLEDGEMENTS}

Ministerio de Educación y Ciencia (Spain) and IFACTT (International Federation of Associations of Textiles Chemists and Colourists) are gratefully acknowledged for financial support.

\section{BIBLIOGRAPHY}

Baldwinson TM. 1990. Colorants and Auxiliaries, 2nd Ed., Society of Dyers and Colourists, Bradford. (UK).

Bordera L, Hernandis V, Canals, A. 1996. Automatic flowinjection system for the determination of heavy metals in sewage sludge by microwave digestion and detection by inductively coupled plasma-atomic emission spectrometry (MW-ICP/AES), Fresenius $\mathrm{J}$. Anal. Chem. 355, 112-119.

CEC, Council of the European Communitites. 1986. Council directive of 12 June 1986 on the protection of the environment, and in particular of the soil, when sewage sludge is used in agriculture (86/278/EEC). Official Journal of the Europeann Communities N. L 181/6-12

Chakraborty R., Das AK, Cervera ML, de la Guardia M. 1996. Literature study of microwave-assisted digestion using electrothermal atomic absorption spectrometry. Fresenius J. Anal. Chem. 355, 99-11.

Clark, EW. 1990.New concepts of lanolin. Manuf. Chem. 61, 18-23

de Pedro E, Casillas M, Miranda CM.1997. Microwave oven application in the extraction of fat from the subcutaneous tissue of Iberian pig ham. Meat Sci. 45, 45-51

Diserens HJ.1989. Simplified extraction and cleanup for multiresidue determination of pesticides in lanolin. J.Assoc. Off. Anal. Chem. 72, 991-993.

García-Ayuso LE, Luque de Castro MD. 1999. A multivariate study of the performance of a microwaveassisted Soxhlet extractor for olive seeds. Anal. Chim. Acta 382, 309-316.

Goode TS.1963. Lanoline woolgrease, a condensed report of the woolgrease industry. J. Am. Oil Chem. Soc. 40, 4-6.

International Wool Secretariat Method, IWS: Report ET708.

Jones FW, Bateup BO, Dixon DR, Gray SR. 1997. Solubility of wool wax in supercritical carbon dioxide. J. Supercrit. Fluids 10, 105-117.
López-Mesas M, Carrillo F, Crespi M. 2003. Microwave enhanced extraction of wool wax from solid wool scour wastes. Anal. Chim. Acta 494, 255-260.

López-Mesas M, Christoe J, Carrillo F, Crespi M. 2005. Supercritical fluid extraction with cosolvents of wool wax from wool scour wastes. J. Supercrit. Fluids 35, 235-239.

Marsal A, Celma PJ, Cor J, Cequier M. 2000. Application of the supercritical CO2 extraction technology on the recovery of natural fat from the sheepskin degreasing process. J. Supercrit. Fluids 18, 65-72.

Martínez,MJ, Crespi M. 1997. Extracción mediante un SOXTEC $\otimes$ de la materia grasa de algodones procedentes de diferentes áreas productoras. Comparación extracción con diclorometano o sucesivas diclorometano-metanol. Grasas Aceites 48. 226-230.

Matusiewicz H, Sturgeon RE. 1989 Application of microwave technique to sample dissolution in analytical chemistry. Prog. Anal. At. Spectrosc. 12, 21-39.

Mingos DMP, Baghurst DR. 1991. Applications of microwave dielectric heating effects to synthetic problems in chemistry. Chem. Soc. Rev. 20, 1-47.

Norman PI, Seddon R.1991. Pollution control in the textile industry-the chemical auxiliary manufacturer's role. $J$. Soc. Dyes Color. 107, 215-218.

Pautes d'Anàlisi en Sòls Contaminats. Generalitat de Catalunya, Departament de Medi Ambient, Junta de Residus.

Pérez-Cid B, Lavilla I, Bendicho C.1999. Application of microwave extraction for partitioning of heavy metals in sewage sludge. Anal. Chim. Acta. 378, 201-210.

Stewart RG, Story LF. 1980. Wool grease: a Review of its Recovery and Utilisation, Technical Papers; Wronz: Christchurch (New Zealand).

Stewart RG. 1966. Amer. Dyest. Reptr. 55, 33.

Stewart RG.1965. Ille Congres International de la Recherche Textile Laniere (CIRTEL), Paris, II, 143.

Sturaro A, Parvoli G, Doretti L. 1993. In Focus. The Tecator Journal of Technology for Chemical Analysis, 17(2), 14.

Sturgeon RE, Willie SN, Methven BA, Lam JWH, Matusiewicz HJ. 1995. Continuous-flow microwaveassisted digestion of environmental samples using atomic spectrometric detection. Anal. At. Spectrom. 10, 981-986.

Walls GW. 1963. Distribution of staple tip in worsted processing of some Merino wools. J. Text. Inst. 54, T79-87.

Recibido: 27/1/06 Aceptado: 4/9/07 